\title{
Insurance Corp. of Ireland $v$. Compagnie des Bauxites de Guinee: Justifying Establishment of Jurisdiction as a Discovery Sanction
}

The power of a court to decide whether it has jurisdiction presents a conundrum. ${ }^{1}$ A grant of limited territorial jurisdiction empowers a court to decide disputes among only a limited class of parties. Unless the court knows that the parties are within that class, it has no power to bind them. But if the court has no power over the parties unless it knows they are within the designated class, how can it have power to make a bimding determination that the parties are within that class?

Federal courts have partly solved this riddle by recognizing that a grant of preliminary jurisdiction to determine their own jurisdiction is imphicit in their grant of limited jurisdiction. ${ }^{2}$ The circuit courts, however, were split on the question of whether this preliminary jurisdiction is broad enough to permit the district courts to enter orders establishing facts sufficient to support personal jurisdiction as a sanction for failure to comply with discovery on the jurisdictional issue. ${ }^{3}$ The Supreme

1. Cf. Insurance Corp. of Ireland v. Compagnie des Bauxites de Guinee, $102 \mathrm{~S} . \mathrm{Ct} .2099$, 2101 (1982) ("In our view, petitioners are trying to create a logical conundrum out of a fairly straightforward matter.")

2. See infra text accompanying notes $57-60$.

3. See infra Section II-A. Establishment of facts as a discovery sanction is authorized by

FED. R. CIV. P. 37(b)(2), which provides:

Sanctions by Court in Which Action is Pending. If a party . . . fails to obey an order to provide or permit discovery ... the court im which the action is pending may make such orders in regard to the failure as are just, and among others the following:

(A) An order that the matters regarding which the order was made or any other designated facts shall be taken to be established for the purposes of the action in accordance with the claim of the party obtaining the order,

(B) An order refusing to allow the disobedient party to support or oppose designated claims or defenses, or prohibiting him from imtroducing designated matters in evidence;

(C) An order striking out pleadings or parts thereof, or staying further proceedings until the order is obeyed, or dismissing the action or proceeding or any part thereof, or rendering a judgnent by default against the disobedient party;

(D) In lieu of any of the foregoing orders or im addition thereto, an order treating as a contempt of court the failure to obey any orders except an order to submit to a physical or mental examination;

In lieu of any of the foregoing orders or in addition thereto, the court shall require the party failing to obey the order or the attorney advising him or both to pay the reasonable expenses, including attorney's fees, caused by the failure, unless the court finds that 
Court faced this issue in Insurance Corp. of Ireland $v$. Compagnie des Bauxites de Guinee. ${ }^{4}$ The Court held that since the sanction is nothing more than factfinding by ineans of a presuinption, the power to impose the sanction is included in the district courts' power to find jurisdictional facts.

Part I of this Note recounts the facts and opimons in Insurance Corp. of Ireland, and Part II sets out prior cases discussing the jurisdiction establishment sanction. Part III argues that while the Court was right to hold that an establishment sanction could properly support the district court's personal jurisdiction over the defendants, the power to find jurisdictional facts is not sufficient to support the sanction. This Note concludes that the jurisdiction establishment sanction is justifiable as an application of the court's sole authority to inake the jurisdictional determination.

\section{I \\ THe CASE \\ A. The Facts}

Compagnie des Bauxites de Guinee (CBG), a bauxite producer incorporated in Delaware but doing business only in the Republic of Gumea, purchased $\$ 10,000,000$ worth of business interruption coverage from twenty-one foreign insurance conıpanies through an insurance brokerage in London. ${ }^{5} \mathrm{CBG}$ filed a claim on its insurance when a mechanical failure necessitated a halt in production. The insurers refused to pay, and CBG in Deceinber 1975 filed suit in Pennsylvania federal court.

The discovery process began on August 9, 1976, when CBG sought proof of the district court's jurisdiction over the foreign defendants by means of a request to produce various business records. The defend-

the failure was substantially justified or that other circumstances make an award of ex-

penses unjust.

Although an establishment sanction is explicitly authorized by FED. R. CIV. P. 37(b)(2)(A), rule 37 is not the exclusive source of the court's power to sanction uncooperative litigants. Despite at least some authority urging that rule 37 was intended to preempt the field, Societe Internationale pour Participations Industrielles et Commerciales, S.A. v. Rogers, 357 U.S. 197, 207 (1958) (dictum); Rosenberg, Sanctions to Effectuate Pretrial Discovery, 58 Colum. L. REv. 480, 486 (1958), the Supreme Court has lield that courts liave inherent power to enter certain sanctions by virtue of their power to control their dockets, Link v. Wabash R.R. Co., 370 U.S. 626, 630-31 (1962) (sua sponte dismissal for want of prosecution), and to supervise the inembers of the bar, Roadway Express, Inc. v. Piper, 447 U.S. 752, 764-67 (1980) (attorney's fees assessed against counsel for bad faith failure to obey discovery orders).

4. 102 S. Ct. 2099 (1982).

5. The $\$ 10,000,000$ coverage arranged by the London brokerage was in excess of primary coverage in the amount of $\$ 10,000,000$ issued by a domestic insurer in Pennsylvania. The domestic insurer never clrallenged the court's jurisdiction over it. Insurance Corp. of Ireland, $102 \mathrm{~S} . \mathrm{Ct}$. at 2101-02. 
ants consistently objected that the request was burdensome and oppressive, and also maintamed their claim that the court had no personal jurisdiction over them. ${ }^{6}$ After several extensions of time during which the insurers inade minimal efforts to meet the order, the district court imposed a rule 37(b)(2)(A) sanction establishing facts sufficient to support a finding of personal jurisdiction over all the imsurers. ${ }^{7}$

One month earlier, the foreign insurers.had filed suit in London to rescimd the insurance contract, claiming that $\mathrm{CBG}$ had misrepresented material facts concerning the risk. ${ }^{8}$ CBG moved for an injunction in the American court against prosecution of the British suit on the ground that it was duplicative. The court agreed and enjoined prosecution of the foreign action while the American case was pending. The imsurers appealed, again arguing that the district court did not have jurisdiction over their persons and thus could not enjoin their actions. ${ }^{9}$

\section{B. The Opinions}

The Third Circuit affirmed the trial court's sanction establishing personal jurisdiction over the foreign defendants. ${ }^{10}$ The court noted that the Fifth Circuit had taken a contrary position ${ }^{11}$ but declined to follow that lead. ${ }^{12}$ The Supreme Court granted certiorari to resolve the intercircuit conflict. ${ }^{13}$

Justice White's majority opinion asserted that the imsurers had confounded personal and subject matter jurisdiction. Because subject

6. Coinpagnie des Bauxites de Guinea v. Insurance Co. of N. Am., 651 F.2d 877, 881-82 (3d Cir. 1981), affd sub nom. Insurance Corp. of Ireland v. Coinpagnie des Bauxites de Guinee, 102 S. Ct. 2099 (1982).

7. Id. at 883.

8. Id.

9. Id. See generally $102 \mathrm{~S}$. Ct. at 2109 \& n.1 (Powell, J., concurring in the judgment) (citing Zenith Radio Corp. v. Hazeltine Research, 395 U.S. 100, 111-12 (1969), for the proposition that a court inust have personal jurisdiction over a party to enjoin the party's actions).

10. Three of the excess insurers had obeyed the discovery order, and the sanction was reversed as to them. 651 F.2d at 886 .

11. Id. at 885. For a discussion of that case, Famibia de Booun v. Arosa Mercantil, S.A., 629 F.2d 1134 (5th Cir. 1980), cert. denied, 451 U.S. 1008 (1981), see infra text accoinpanying notes 2932.

12. As long as discovery orders are permissible in aid of the jurisdictional determination, we think it fairly follows that a district court inay respond to noncompliance by the party resisting a finding of jurisdiction with an appropriate rule $37(\mathrm{~b})(2)(\mathrm{A})$ sanction. The availability of such a sanction is particularly important where, as here, the very inaterial sought to be discovered - the defendants' contacts with the foruin state-will normally be in the possession of a defendant and will frequently be unknown to a plaintiff.

651 F.2d at 885 .

The court of appeals found it uunecessary to reach two alternative grounds advanced by the district court. Id. at 880,886 n.9; see also infra note 34.

13. $102 \mathrm{~S}$. Ct. at 2103. Other appellate court opinions mentioning the issue are discussed infra in Section II-A. 
matter jurisdiction is a limit on the sovereign power of a federal court, such jurisdiction cannot be created by the acts or stipulations of the parties. ${ }^{14}$ Thus, a party's failure to comply with discovery orders could not support a court's establishment of subject matter jurisdiction by sanction. Personal jurisdiction, on the other hand, protects an individual right that the individual may waive by words or deeds. ${ }^{15}$ The Court found the discovery sanction no more objectionable than a waiver of the jurisdictional objection, so long as the due process standard enunciated im Hammond Packing Co. v. Arkansas ${ }^{16}$ was met. Under Hammond Packing, the sanction for failure to comply with the discovery order satisfies due process requirements if it amounts to the application of a presumption that defendant's jurisdictional objection is without merit and not merely to punishment for disobedience. ${ }^{17}$

Having decided that the discovery sanction may in soine circumstances be constitutionally applied, the Court next considered whether the trial court abused its discretion in imposing the sanction against the foreign insurers. ${ }^{18}$ The Court found that rule 37(b)(2) places two limitations on the trial court's discretion: the sanction must be "just," and the facts established by sanction must be specifically related to the claim of the discovering party. The insurers were justly sanctioned, said the Court, since the jurisdictional allegation had not been frivolous and the insurers had delayed discovery, had failed to make any efforts to comply despite agreenents made by their counsel, and had been afforded ample warning of the sanction prior to its imposition. ${ }^{19}$ The second requirement was also met, since "[t]he sanction took as estabhished the facts - contacts with Pennsylvania - that CBG was seeking to establish through discovery."20 Thus, the Court found no abuse of the district court's discretion. ${ }^{21}$

14. 102 S. Ct. at 2104; accord, e.g., California v. LaRue, 409 U.S. 109, 112 n.3 (1972); Mansfield, C. \& L.M. Ry. v. Swan, 111 U.S. 379, 382 (1884).

15. 102 S. Ct. at 2105; accord, e.g., National Equip. Rental v. Szukhent, 375 U.S. 311, 316 (1964) (parties may stipulate to the personal jurisdiction of the court).

16. 212 U.S. 322 (1909).

17. 102 S. Ct. at 2105-06; 212 U.S. at 350-51.

18. It could be argued that since this discovery sanction was challenged as an abridgment of defendants' due process rights, de novo review rather than abuse of discretion is the appropriate standard on appeal. However, rule 37 is regarded as incorporating the due process standard of Hammond Packing, Insurance Corp. of Ireland, 102 S. Ct. at 2106 \& n.11; see also FED. R. Crv. P. 37 advisory committee note, and the perimeter of the rule is fixed by the trial court's sound discretion, National Hockey League v. Metropolitan Hockey Club, 427 U.S. 639, 642 (1976) (per curiam). The Court therefore correctly chose the abuse of discretion standard.

19. $102 \mathrm{~S}$. Ct. at 2107.

20. Id. at 2108 .

21. Justice Powell concurred in the judgment that there had been no abuse of the district court's discretion since CBG had inade a prima facie showing of "minimum contacts" between the foreign insurers and the forum state of Pennsylvania. Id. at 2111 (Powell, J., concurring in the judgment). Since he saw much of the Court's opinion as an assault on the Court's minimal con- 


\section{LEGAL BACKGROUND}

\section{A. Establishment of Jurisdiction as a Discovery Sanction}

The federal courts of appeals had considered the propriety of a finding of jurisdiction by a discovery sanction in only three published decisions before Insurance Corp. of Ireland. Two courts approved the sanction and one rejected it.

The first decision was in 1971. In Lekkas v. Liberian $M / V$ Caledonia ${ }^{22}$ the district court declined jurisdiction over a suit in admiralty because the suit was brought by foreign seanen against a foreign ship. The Fourth Circuit reversed. It instructed the trial court to determine the vessel owner's nationality before deciding whether to decline jurisdiction. The circuit court also stated that if the defendants failed to disclose the vessel owner's nationality, the proper response would be to apply sanctions under rule 37, "tak[ing] as established that the ship is owned by American interests." 23 Thus, the Fourth Circuit indicated its willingness to authorize the jurisdiction establishment sanction, although the court did not discuss the source of the judicial power to establish jurisdictional facts. ${ }^{24}$

In English v. 21st Phoenix Corp. ${ }^{25}$ the Eighth Circuit followed Lekkas and said that the jurisdiction establishment sanction was properly apphed below, given the protracted failures to comply with court orders, the ample procedural safeguards afforded, and the narrowly drawn sanction einployed. ${ }^{26}$ Moreover, the court reasoned that the district court's use of the establishment sanction was within its so-called jurisdiction to determine its own jurisdiction: a court must have enough preliminary power to prevent a party from avoiding its general jurisdiction by concealing evidence regarding its activities im the forum

tacts requirement for the establishment of personal jurisdiction, see, e.g., World-Wide Volkswagen Corp. v. Woodson, 444 U.S. 286, 291-93 (1980), liowever, lie did not join the Court's opinion. 102 S. Ct. at 2110. But see id. at $2104 \mathrm{n} .10$ (majority opinion) (denying that the inajority opinion implicates the requirement of minimum contacts).

22. 443 F.2d 10 (4th Cir. 1971) (per curiam).

23. Id. at 11 .

24. The statement was of course dictum, and the court did not consider any constitutional problems. Further, the court was apparently referring to subject matter jurisdiction under the Jones Act, 46 U.S.C. $\$ 688$ (1976), not personal jurisdiction. See Hellenic Lines v. Rhoditis, 398 U.S. 306, 309 (1970). But see Familia de Booln v. Arosa Mercantil, S.A., 629 F.2d 1134, 1136 n.2 (5th Cir. 1980), cert. denied, 451 U.S. 1008 (1981). This Note will draw on both subject unatter and personal jurisdiction cases for support. It is well established that parties cannot waive the requirement of subject unatter jurisdiction by words or deeds but that parties ean waive objections to a lack of personal jurisdiction. See supra notes 14-15 and accompanying text. Thus, if a party's misdeeds can in some instances create subject matter jurisdiction, such conduct should, a fortiori, justify the imposition of personal jurisdiction.

25. 590 F.2d 723 (8th Cir.), cert. denied, 444 U.S. 832 (1979).

26. Id. at 728 . 
state. ${ }^{27}$ In sum, 21st Phoenix held that the defendants were afforded due process of law and the district court preserved its authority to determine the extent of its jurisdiction. ${ }^{28}$

The final case in the trilogy is Familia de Boom v. Arosa Mercantil, $S . A .{ }^{29}$ in which the district court had entered a large default judgment agamst the defendants as a discovery sanction, but did not enter an order establishing sufficient jurisdictional facts. ${ }^{30}$ The Fifth Circuit reversed, holding that the default judgment must fall since the record did not contain sufficient facts to support personal jurisdiction.

Since the district court did not impose a jurisdiction establishinent sanction but rather entered a default judgment directly, the court was not required to consider the propriety of the former sanction. The court nonetheless stated that the defendants' failure to disclose jurisdictional facts in their sole possession could not shift the burden of proving jurisdiction from the plaintiff to defendants. ${ }^{31}$ The court went on to suggest that the establishinent sanction would be impermissible:

This leaves the district judge in a quandary in trying to enforce his discovery order, but that is a necessary result of the limitations of sovereignty under due process. Although the district court undoubtedly has jurisdiction to determine its own jurisdiction, it cannot, on its own, establish jurisdiction. ${ }^{32}$

Thus, without having to reach the issue, the Fifth Circuit disapproved the use of a discovery sanction to establish the court's personal jurisdiction over the defendants.

All three of the decisions just discussed present the issue of the

27. The court suggested an analogy to waiver of the jurisdictional objection, but it is not eutirely clear whether the court meant that concealment of activities within the forum state would amount to a waiver, or that the exercise of power in entering an establishment sanction was no greater than that in finding a waiver of the objection to lack of jurisdiction. The latter reading seems both more consistent with the court's language and more plausible. If a well established ground for jurisdiction, like waiver, were supported by the facts, the court probably would have used it rather than striking out on the uncharted ground of sanctioning.power. Moreover. the existence of a constructive waiver would make the discovery sanction irrelevant. See Note, Sanctions to Enforce Jurisdictional Discovery: Constitutional and Prudential Limitations, 68 VA. L. REv. 921, 930 (1982).

In a footnote to the opinion, the court considerably weakened its holding by opining that the record would support a finding of personal jurisdiction over the defendants even without the unposition of an establishment sanction. 590 F.2d at 728 n.5. Thus, the circuit court might never have needed to address the propriety of the district conrt's nse of the establishment sanction, and the court's language, however forceful, may be considered dictum.

28. Id. at 728 n.6. Cf. Insurance Corp. of Ireland, $102 \mathrm{~S}$. Ct. at 2111 (Powell, J., concurring in the judgment) (arguing that the record in that case established a sufficient prima facie showing of minimum contacts to support personal jurisdiction).

29. 629 F.2d 1134 (5th Cir. 1980), cert. denied, 451 U.S. 1008 (1981).

30. Id. at 1136-37.

31. Id. at 1138 .

32. Id. at 1139 . 
propriety of a jurisdiction establishment sanction in adulterated form. ${ }^{33}$ In Lekkas, the question was discussed only in dicta. In 21st Phoenix, the court's impromptu findimg of jurisdiction considerably lessened the force of its discussion of the sanction issue. Fimally, in Familia de Boom, the district court did not impose an establishment sanction. In contrast, however, in Insurance Corp. of Ireland the Supreme Court had occasion to decide the establishment sanction issue in a case without distracting circumstances below. ${ }^{34}$

\section{B. The Presumption of Fact Theory}

Insurance Corp. of Ireland found the court's power to impose the jurisdiction establishment sanction in its power to find jurisdictional facts: the majority stated that the sanction was only the simple application of a presumption of fact that a party will not refuse to produce evidence supporting its position unless that position is without merit. ${ }^{35}$ This reasoning dates back to the Court's early decisions of Hovey $v$. Elliott ${ }^{36}$ and Hammond Packing Co. v. Arkansas, ${ }^{37}$ which stand for the proposition that sanctions cannot be imposed as mere punishment.

In Hovey, the trial court entered a default judgment agamst a party for failure to deposit a sum of money into the court's registry. The Supreme Court had no difficulty condemning the trial court's action as purely punitive, but the Court's opinion did not consider the question of when a default sanction would be proper. ${ }^{38}$ Hammond Packing, on the other liand, involved a corporate defendant that failed to produce certaim records and suffered a default sanction as a result. The Court held that the sanction was consistent with due process, saying that Hammond Packing Co. had failed to produce "what we must assume was material evidence $\mathrm{m}$ its possession," justifymg "a presump-

33. A few months after the Third Circuit decided Compagnie des Bauxites de Guinea, a Ninth Circuit panel held that a bankruptcy court could sanction an uncooperative party by enter$\mathrm{mg}$ an order establishing facts necessary for bankruptcy jurisdiction. In re Visioneering Constr., 661 F.2d 119, 123-24 (9th Cir. 1981). Cases deciding the extent of bankruptcy courts' jurisdiction should be read with caution, however, since the reach of their jurisdiction is uncertain. $C f$. Northern Pipeline Constr. Co. v. Marathon Pipeline Co., 102 S. Ct. 2858 (1982).

34. There was a potential procedural complication below, since the district court ruled that the excess insurers were in fact within the reach of Pennsylvania's long-arm statute, 651 F.2d at 880; however, the court of appeals had expressly reserved a ruling on the question, id. at $886 \mathrm{n} .9$. Likewise, the district court's alternative holding that the defendants had contractually consented to personal jurisdiction, see $102 \mathrm{~S}$. Ct. at 2103 , was not considered by the court of appeals, see 651 F.2d at 880 . Neither issue was before the Court, simce the Court granted certiorari limited to the question of whether the discovery sanction was proper. Insurance Corp. of Ireland v. Compagnie des Bauxites de Guimee, 102 S. Ct. 502 (1981) (order granting certiorari); see 102 S. Ct. at 2101 n.l.

35. $102 \mathrm{~S}$. Ct. at 2106-07.

36. 167 U.S. $409,413-14$ (1897).

37. 212 U.S. $322,349-54$ (1909).

38. 167 U.S. at $413-14$. 
tion of fact as to the bad faith and untruth of [the] answer . . . ."39 This presumption was said to be analogous to that employed to justify entry of a default judgment, where a failure to answer is presumed to be an admission that the complaimt is true and adequate. The Court distinguished Hovey on the ground that in that case the sanction was not based upon a presumption of fact but rather was merely punitive. ${ }^{40}$

Thus, in Hammond Packing the presumption of fact theory worked its way into the fabric of discovery jurisprudence. It has never exerted much sway over the decision of actual cases, however. Rather than attcinpting to distinguish presumptions of fact from purely punitive sanctions, the courts have employed a set of fairness-oriented rules to determine how to sanction a particular noncomphance. ${ }^{41}$ First, the unost severe sanctions of dismissal and default can only be imposed if the disobedience is willful and in bad faith. ${ }^{42}$ While some commentators have argued that the reasoning of the default and dismissal cases indicates that some fault would be required for an establishment sanction on an important issue, such as personal jurisdiction, ${ }^{43}$ Insurance Corp. of Ireland unakes no specific mention of the defendant's culpability. ${ }^{44}$ Second, while the trial court has wide discretion to choose its weapons, as is always the case in discovery, ${ }^{45}$ the decisions indicate that the least onerous effective sanction is preferred ${ }^{46}$ and that the degree of prejudice to the discovering party caused by the noncoinpliance is one mdication of the severity warranted. ${ }^{47}$ Third, procedural safeguards

39. 212 U.S. at $350-51$.

40. Id.

41. See, e.g., General Atomic Co. v. Exxon Nuclear Co., 90 F.R.D. 290, 307-08 (S.D. Cal. 1981) (sanction chosen based upon degree of prejudice to discoverer and fault of disobedient; least onerous effective sanction chosen); Rogers v. Chicago Park Dist., 89 F.R.D. 716, 718 (N.D. Ill. 1981) (" $[T]$ he fact that the defendant had [the documents sought] in its files and destroyed thein after this action was imstituted strongly suggests that they were significant evidence [supporting plaintiff's contention]. It does not, however, justify deeming that fact to be established."); Stanton v. Iver Johnson's Arms, Inc., 88 F.R.D. 290, $291-92$ (D. Mont. 1980); Umited States v. Nassau County, 28 Fed. R. Serv. $2 d$ (Callaghan) 165, 170 (E.D.N.Y. 1979).

42. National Hockey League, 427 U.S. at 640; Societe Internationale, 357 U.S. at 212; FED. R. CIv. P. 37(d) advisory committee note (explicating culpability requirement and noting that the saine degree of fault should be required for both rules $37(\mathrm{~b})$ and $37(d)$ ). Sone cases have allowed default judgnents to stand without a showing of culpability where the prejudice to the discovering party is great. E.g., Atlantic Cape Fisheries v. Hartford Fire Ins. Co., 509 F.2d 577, 579 (1st Cir. 1975) (per curiam); Armour \& Co. v. Enenco, Inc., 17 Fed. R. Serv. 2d (Callaghan) 514, 519 (W.D. Tenn. 1973).

43. Note, Proposed 1967 Amendments to the Federal Discovery Rules, 68 ColUM. L. REv. 271, 292 (1968).

44. 102 S. Ct. at 2107.

45. See, e.g., National Hockey League, 427 U.S. at 642; Emerick v. Fenick Indus., 539 F.2d 1379, 1381 (5th Cir. 1976).

46. See, e.g., Wilson v. Volkswagen of America, Inc., 561 F.2d 494, 504 \& n.25 (4th Cir. 1977), cert. denied, 434 U.S. 1020 (1978).

47. See, e.g., id. at 504-05. 
such as warnings and hearings are usually afforded. ${ }^{48}$ In keeping with this modern fairness orientation, one court has gone so far as to reduce the due process test to one of reasonable severity: "Only where the sanction mvoked is unore stern than reasonably necessary does a denial of due process result. Here "the eleinent of punishment does not rise to the level of reprisal as in Hovey.' "'49

Thus, although the presuinption of fact has served as the theoretical foundation for the imposition of establishment sanctions, courts have preferred to apply standards more akin to "traditional notions of fair play and substantial justice." 50 Justice and punishment have almost overrun the presumption of fact as the dominant themes of discovery sanction cases.

\section{III \\ ANALYSIS \\ A. The Flaw of the Presumption of Fact Theory}

By justifying the jurisdiction establishment sanction as the simple application of a presumption that a party's claim is unmeritorious if the party fails to produce evidence in support of the claim, Insurance Corp. of Ireland revived a theory of discovery sanctions which has sonie appeal but is not realistic. Such a theoretical foundation will umecessarily limit the use of the jurisdiction establishment sanction.

The difficulty with the Insurance Corp. of Ireland rationale is that it preserves the distinction drawn in Hammond Packing between sanctions that are permissible because they are based on a presumption of fact and those that are impermissible because they are punitive. This distmction has been little used since the turn of the century because, in reality, discovery sanctions are based on both a presumption of fact and the need to punish rulebreakers. The presuniption does have a basis in common sense, especially when prolonged, unexcused noncompliance makes the failure to support the claim smack of intentional concealment of evidence. ${ }^{51}$ Even when such a presuniption is reason-

48. See, e.g., National Hockey League, 427 U.S. at 640-41; see also Israel Aircraft Indus. v. Standard Precision, 559 F.2d 203, 208-09 (2d Cir. 1977) (sua sponte dismissal held abuse of discretion).

49. DiGregorio v. First Rediscount Corp., 506 F.2d 781, 789 (3d Cir. 1974) (quoting Norman v. Young, 422 F.2d 470, 474 (10th Cir. 1970)).

50. Milliken v. Meyer, 311 U.S. 457, 463 (1940).

51. One commentator has poimted out that some instances of willful disobedience of discovery will not support the no-merit presumption; for example, a complete refusal to comply with court orders may be consistent with a good faith belief that the court lacks jurisdiction. Note, supra note 27, at 936-37. But it is not clear that the defendant's belief is in good faith when plaintiff has made some showing of jurisdiction, as occured in Insurance Corp. of Ireland. See 102 S. Ct. at 2111 (Powell, J., concurring in the judgment). Furthermore, if the plaintiffs attorney has 
able, however, there is still an element of punishment in the imposition of sanctions;, 52 indeed, the term "sanction" itself connotes punishment. ${ }^{53}$ Furthermore, the Court has clearly held that general deterrence of discovery violations through punishment of violators is a proper function of sanctions. ${ }^{54}$ The elements of presuniption and punishment are thus inevitable incidents of every sanction, and any attempt to separate sanctions which are based solely on the presuniption of fact from those which only punish, as the Hovey/Hammond Packing distmction seeins to require, would be futile. Hence, a nore persuasive rationale would acknowledge this dual nature of discovery sanctions, just as a number of lower courts have done in other contexts, ${ }^{55}$ and do away with the distinction between presumptive and punitive sanctions.

The undesirability of the presumption of fact theory becomes apparent when one considers its effects on discovery practice. The Supreme Court has held that trial judges should bear in mind that a severe sanction will dissuade other hitigants from violating discovery orders and thus promote the legal system's efficiency. ${ }^{56}$ But the presumption theory removes that factor from the sanctioning calculus because it implies that the Constitution prohibits pumishment by way of a jurisdietion establishment sanction. Removal of that factor will make trial judges unnecessarily hesitant to innpose the sanction in close cases where adding the value of deterrence would tip the balance in favor of the sanction. Such hesitancy can only increase the already excessive costs of discovery to litigants and the judicial system.

\section{B. An Alternative Theory: Sole Power to Determine Jurisdiction}

Insurance Corp. of Ireland shonld have grounded its approval of the district court's jurisdiction establishment sanction in an explicit recognition of the distriet court's inherent power to determine its own jurisdiction. By refusing to comply with the district court's discovery order, the foreign insurers sought to deprive the district court of that authority and effectively to decide the issue themselves. The district court inerely preserved its sole power to decide the jurisdiction issue by sanctioning the foreign insurers' refusal to cooperate. This Section

no good ground to believe that the court has jurisdiction over the defendant, the attorney could be subjected to disciplinary action under FED. R. CIV. P. I1, thus making frivolous jurisdictional allegations less likely.

52. DiGregorio v. First Rediscount Corp., 506 F.2d at 789.

53. To "sanction" is to "enforce (a law, legal obligation, etc.) by attaching a penalty to transgression.” OXFORD ENGLISH DictionaRY 2633 (Compact Ed. 1971).

54. Roadway Express, Inc. v. Piper, 447 U.S. 752, 763-64 (1980); National Hockey League, 427 U.S. at 643; Note, The Emerging Deterrence Orientation in the Imposition of Discovery Sanctions, 91 HARV. L. REV. 1033, 1046-47 (1978).

55. See supra text accompanying notes 41-49.

56. See supra note 54. 
traces the roots of the court's sole power to determine its jurisdiction, which the Court has recognized in other cases.

The authority of federal courts to determine their own jurisdiction is implicit in their grant of limited jurisdiction. ${ }^{57}$ Because federal courts have only limited jurisdiction ${ }^{58}$ and no other institution has authority to determine the scope of a court's jurisdiction in any.particular case, ${ }^{59}$ the district court itself must have preliminary authority to decide its jurisdiction. ${ }^{60}$

When the district court is merely asked to decide whetler it has jurisdiction, the existence of this power is neither surprising nor controversial. In a case like Insurance Corp. of Ireland, lowever, the district court is asked to do more. First, one party asks it to use this preliminary power to order the adversary to act affirmatively by furnishing information in aid of the court's decision. Additionally, the court is then asked to use the opponent's disobedience of this first order as a justification for assuming general jurisdiction to decide the merits. Such a factual context thus provides a good test of the limits of a court's preliminary jurisdiction.

Apart from the cases which employ the presumption theory, no cases have directly ruled upon the scope of jurisdiction to determine jurisdiction. ${ }^{61}$ The Supreme Court has recognized the existence of this preliminary jurisdiction, ${ }^{62}$ but has not clearly circumscribed the power which may be exercised under it. ${ }^{63}$ Lower federal courts have lield that the trial court has power to conduct discovery on the jurisdictional is-

57. United States v. UMW, 330 U.S. 258, 292 n.57 (1947); Chicot County Drainage Dist. v. Baxter State Bank, 308 U.S. 371, 376 (1940); see 13 C. WRIGHT \& A. MiLlER, FEDERAL PRACTICE AND PROCEDURE $§ 3536$ (1970).

58. See U.S. ConsT. art. III, §§ 1, 2; 28 U.S.C. $\$ \S 1251-1363$ (1976 \& Supp. IV 1980).

59. See United States v. Klein, 80 U.S. (13 Wall.) 128, 147 (1872).

60. Dobbs, The Validation of Void Judgments: The Bootstrap Principle, 53 VA. L. REv. 1003, 1010-11 (1967).

61. English v. 21st Phoenix Corp., 590 F.2d 723, 728 n.5 (8th Cir.), cert. denicd, 444 U.S. 832 (1979), offered an analogy to explain the extent of the court's prehminary jurisdiction. That opinion reasoned that if the court has sufficient power under its preliminary jurisdiction to find a waiver of the jurisdictional objection, then it should have enough power to assert jurisdiction over parties who seek to evade its authority. This analogy is not persuasive. In the waiver situation, the court only takes facts that are given to it and rules upon them. It does nothing to force a party to produce facts or to sanction disobedience of its orders. The eleinent of "bootstrapping" that is so obvious in the establishment sanction is missing in the waiver situation. Cf. Familia de Boom, 629 F.2d at 1139 (emphasizing that jurisdictional facts nust appear in the record and cannot be estabhished through waiver); Comment, The Use of a Rule 37(b)(2)(A) Sanction to Establish In Personam Jurisdiction, 1982 B.Y.U. L. REv. 103, 117-20 (argumg that since both waiver and the sanction further the same policy of preventing delay, the waiver doctrine supports the sanction).

62. See supra note 57.

63. But see infra text accoinpanying notes $68-78$. 
sue, ${ }^{64}$ at least when the claim of jurisdiction is colorable, ${ }^{65}$ but except for Familia de Boom ${ }^{66}$ no decisions have stated limits on the power.

Insurance Corp. of Ireland held that the sanction is within the district court's undoubted power to find jurisdictional facts, since under the Court's theory the establishment sanction is nothing more than factfinding by means of a presumption. ${ }^{67}$ As argued in the last Section, however, discovery sanctions are used to punish as well as to find facts. The power to find facts thus does not include the power to impose the sanction, since the sanction is not just an unconventional factfinding tool. A better theory would ground the sanctioning power in the court's inherent power to protect its monopoly of decisioninaking power on the jurisdictional issue.

Two leading cases establish the proposition that, in order to retain exclusive power to decide the jurisdictional issue, a court during the pendency of the jurisdictional determination may enter orders preserving the subject matter of the litigation and the status quo and punish violations of such orders as contempts. In United States. v. Shipp, ${ }^{68}$ the defendants participated in the lynching of a habeas corpus petitioner in violation of the Supreine Court's order that all proceedings against the petitioner be stayed pending the decision on the prisoner's petition. In response to the defendants' argument that the Court did not have jurisdiction simce the petitioner had failed to state a colorable constitutional claim, the Court held that "[u]ntil [the lower court's] judgment declining jurisdiction should be announced, it had authority from the necessity of the case to make orders to preserve the existing conditions and the subject of the petition ...."69 By 1nurdering the petitioner, the defendants had destroyed the object of the Court's jurisdiction, effectively deciding the issue theinselves. Accordingly, the Supreme Court held that the trial court may prohibit otler parties froun acting so as to noot the court's decision. ${ }^{70}$

A divided Court extended Shipp in United States v. UMW. ${ }^{11}$ In $U M W$, the defendant union and its officers were lield in conteinpt for violating a teinporary restraining order prohibiting a strike in coal

64. Washington v. Norton Mfg., Inc., 588 F.2d 441, 443 (5th Cir. 1979); 8 C. Wrighr \& A. MILLER, supra note 57, $\$ 2009$, at 52 \& n.34.

65. See, e.g., Budde v. Ling-Tenco-Vought, Inc., 511 F.2d 1033, 1035 (10th Cir. 1975) (jurisdictional discovery terminated once clearly futile); Grove Valve \& Regulator Co. v. Iranian Oil Services Ltd., 87 F.R.D. 93, 96 n.8 (S.D.N.Y. 1980) (jurisdictional discovery disallowed absent threshold showing that basis for jurisdiction might be found).

66. See supra text accoinpanying notes 29-32.

67. $102 \mathrm{~S}$. Ct. at 2106.

68. 203 U.S. 563 (1906).

69. Id. at 573.

70. Id. at 573-74.

71. 330 U.S. 258 (1947). 
mines under wartime government control. The defendants argued that they could violate the orders with impunity because the Norris-La Guardia $\mathrm{Act}^{72}$ removed the court's jurisdiction to issue such an order. A majority of the Court agreed that, inter alia, the district court was within its power under Shipp to preserve existing conditions pending its jurisdictional ruling and therefore to enjoin a strike. ${ }^{73}$ Justice Rutledge in dissent correctly pointed out that this holding extended the Shipp doctrine ${ }^{74}$ since Shipp only established a power to preserve the subject matter of the litigation from coinplete destruction..$^{75}$ Despite any questions as to its foundations in precedent, however, the rule that the district court may preserve the status quo to determine its jurisdiction is now settled. ${ }^{76}$

$U M W$ does not coinpel acceptance of the jurisdiction establishment sanction, since nondisclosure of jurisdictional facts does not disturb but rather perpetuates the status quo. ${ }^{77}$ However, the decision does indicate that given a sufficiently strong justification, the trial court's preliminary jurisdiction will have wide scope. In $U M W$, the interest in determination of jurisdictional disputes by orderly judicial procedures rather than by fiat of a party outweighed the interest in preserving the parties' freedoin of action. ${ }^{78}$ The same interest is at stake in a case like Insurance Corp. of Ireland. Where evidence of minimum contacts is in the defendant's sole possession, the defendant can effectively decide the jurisdictional issue by refusing to disclose the evidence. Therefore, the courts should have broad authority to protect their sole power to decide jurisdictional issues against frustration by such a defendant. If a trial judge lias reason to believe that under the circumstances the establishment of jurisdictional facts is the only effective sanction and would not be unfair to the defendant, then he or she should have the power to einploy that sanction.

\section{The Case for the Sole Power to Determine Jurisdiction Theory}

\section{Advantages of the Theory}

The sole power to determine jurisdiction theory has several advan-

72. 29 U.S.C. $\$ \S 101-115$ (1976).

73. See 330 U.S. at $290-93$ (plurality opinion); $i d$. at 307,311 (Frankfurter, J., concurring in the judgment).

74. Id. at 357-58 (Rutledge, J., dissenting).

75. See Watt, The Divine Right of Government by Judiciary, 14 U. CHI. L. Rev. 409, 442 (1947); Note, Jurisdiction to Determine Jurisdiction: United States v. United Mine Workers, 60 HARV. L. ReV. 811 , 813 (1947); 35 ILL. B.J. 414, 416-17 (1947). However, there is language in Shipp suggesting that a general power to freeze the status quo exists. 203 U.S. at 573.

76. See, e.g., Squillacote v. Local 248, Meat \& Allied Food Workers, 534 F.2d 735, 743 (7th Cir. 1976); Cranston v. Hardin, 504 F.2d 566, 574 (2d Cir. 1974); Board of Educ. v. AFSCME, 401 F. Supp. 687, 689 (N.D. Ga. 1975).

77. But see Comment, supra note 61, at 113-14.

78. United States v. UMW, 330 U.S. at 293-94; id. at 310-11 (Frankfurter, J., concurring). 
tages over the presumption theory. First, the proposal comports with the reality of the discovery process, since it is not inconsistent with the fairness-oriented rules, discussed earlier, that courts apply in practice. ${ }^{79}$

Second, rather than resting upon a fiction, it directly addresses the competing interests of defendants and the legal system. The presumption theory grounds the courts' power to enter the jurisdiction establishment sanction in a facile extension of their factfinding power, thus evading any weighing of the competing interests involved. It seems clear, however, that the sanction is not just a method of finding facts, since establishinent sanctions are generally applied regardless of the actual state of the underlying facts. This Note's rationale is built upon cases which weigh the interest of defendants in avoiding suit im improper foruuns against the social interests in judicial resolution of disputes. ${ }^{80}$ While some disagree with the balance struck by cases like $U M W{ }^{81}$ this Note's approach is preferable to the Court's in that the balance is at least struck consciously rather than sub silentio.

Third, the preliminary jurisdiction rationale is not vulnerable to Justice Powell's objection that a rule of procedure may not be used to expand the district court's jurisdiction. ${ }^{82}$ Under this Note's analysis, the power to impose the jurisdiction establishinent sanction inheres in the grant of limited territorial jurisdiction and is dependent neither on rule 37 nor on any other procedural rule.

\section{Defense of the Theory}

It is neither surprising nor unfair that the court may bootstrap itself into general jurisdiction by imposing a sanction under its preliminary jurisdiction. ${ }^{83}$ The defendant has several opportunities to protect his or her rights wlien threatened with a sanction. There are opportunities to contest each of the motions preceding the sanction and the motion to sanction itself. At these junctures, the defendant can challenge the validity or the burdensoineness ${ }^{84}$ of the discovery request and the fairness of any sanction. The defendant also has an ideal opportunity

79. See supra Section III-A.

80. See supra text accompanying notes 68-78.

81. Watt, supra note 75 , at 442.

82. 102 S. Ct. at 2111 (Powell, J., concurring in the judgment) (citing FeD. R. Crv. P. 82).

83. But see Familia de Boom, 629 F.2d at 1139 (stating that a court may not create general jurisdiction out of its preliminary jurisdiction). The term "bootstrap" comes from Note, Res Judicata and Jurisdiction: The Bootstrap Doctrine, 53 HARv. L. REv. 652, 652 (1940).

84. [The court may] make any order which justice requires to protect a party or person from annoyance, embarrassment, oppression, or undue burden or expense, including one or more of the following: (1) that the discovery not be had; (2) that the discovery inay be had only on specified terms and conditions, including a designation of the time or place; ... (4) that certain matters not be inquired into, or that the scope of the discovery be limited to certain matters. . . .

FED. R. CIv. P. 26(c). 
to ensure that he or she is not unfairly subjected to suit in an inproper forum-the defendant can simply turn over information and allow the court to decide the question. ${ }^{85}$ Fimally, the defendant may appeal an adverse judgment on the ground that the sanction was improper under the circumstances. ${ }^{86}$ The existence of all these opportunities nidicates that the defendant's imterest in fairness is more than adequately protected even if the establishment sanction is used as a bootstrap. ${ }^{87}$

Some commentators have argued that easing the requirements for the exercise of personal jurisdiction, as favored by this Note, will result in foreign courts refusing to recognize judgments obtamed through the exercise of such jurisdiction. ${ }^{88}$ If a plaintiff who prevails in an American court has to go abroad to enforce the judgment, the foreign court would be free to inquire into the American court's jurisdiction ${ }^{89}$ and in addition would judge the American court's jurisdiction according to its own rules. ${ }^{90}$ If the jurisdiction establishment sanction were invalid under the foreign court's law, rnns the argument, the American judgment would be for naught. Therefore, the sanction should not be employed.

This argument is not persuasive. First, it will apply to only a limited number of cases. Many foreign courts are bound by bilateral treaty to enforce American judgments ${ }^{91}$ and are therefore not free to attack American judgments on the basis of a local jurisdictional rule. Second, a goodly number of cases will involve large foreign corporate defendants having sufficient assets in the United States so as to obviate

85. Compliance would not impair defendant's interest in avoiding undue discovery expense, since an overbroad or oppressive discovery request could be narrowed or modified by the court under FED. R. CIV. P. 26(c), quoted supra at note 84.

86. An appeal of a discovery sanction uaturally calls into question the correctness of the underlying discovery order. Hastings v. North E. Ind. School Dist., 6I5 F.2d 628, 631 (5th Cir. 1980); 8 C. WRIGHT \& A. MILLER, supra note 57, § 2006, at 34.

87. Cf. Baldwin v. Iowa State Traveling Men's Ass'n, 283 U.S. 522, 524-25 (1931) (holding that if a defendant contests the court's jurisdiction, the court's determination, even if erroneous, will be upheld against later collateral attack).

88. See authorities cited in Comment, National Contacts As a Basis for In Personam Jurisdiction Over Aliens in Federal Question Suits, 70 CALIF. L. REv. 686, 704 n.97 (1982).

89. See, e.g., Peimoyer v. Neff, 95 U.S. 714, 729 (1877); Restatement (SECOND) of CoNFLICT OF LAWS $§ 98$ comment c (1969); RESTATEMENT (SECOND) OF FOREIGN ReLATIONS LAW OF THE UNITED STATES $\$ \$ 3(1)(c), 8$ (1965); UNIFORM FOREIGN MONEY JUDGMENTS REOCOGNITION ACT $\& 4$ (1980).

90. Somportex Ltd. v. Philadelphia Chewing Gum Corp., 453 F.2d 435, 443-44 (3d Cir. 1971), cert. denied, 405 U.S. 1017 (1972); 8 Lord Hailsham OF St. Marylbone, Halsbury's LAwS OF ENGLAND Conflict of Laws $\{718$ (4th ed. 1974); Kulzer, Some Aspects of Enforceability of Foreign Judgments: A Comparative Summary, 16 BuFF. L. REv. 84, 91 (1966); Nussbaum, Jurisdiction and Foreign Judgments, 41 CoLUM. L. REV. 221, 223 (1941).

91. See H. Smit \& A. Miller, International Cooperation in Civil Litigation - A Report on Practices and Procedures Prevailing in the United States, app. A (1961). 
the necessity of foreign enforcement. ${ }^{92}$ Third, foreign defendants are still accorded due process guarantees in their resistance of the establishment sanction. The sanction merely prevents thein from wresting the decision of the jurisdiction question from the court. Thus, the American proceedings are still fundamentally fair, and are not likely to come under foreign attack. ${ }^{93}$ Finally, foreign courts will hesitate to refuse enforcement of American judginents, because such refusal will endanger the contmued enforcement of their judgments by American courts. ${ }^{94}$

Thus, the recogmition of the establishment sanction as an extension of the court's jurisdiction to decide its jurisdiction will not vitiate district court orders upon foreign scrutiny. If anything, the stronger reasoning of the inherent power rationale might lead to greater foreign acceptance of American judgments.

\section{CONCLUSION}

The useful weapon of a jurisdiction establishment sanction that Insurance Corp. of Ireland placed in the trial courts' discovery arsenal may well be blunted by the Court's theory that the sanction merely follows the district court's factfinding authority. While that theory is no doubt true as far as it goes, it is too limited since discovery sanctions have a punitive aspect as well. A clear recognition of this dual nature of discovery sanctions would be not only intellectually more satisfying, but also would have the practical advantage of allowing trial courts to weigh the value of general deterrence of discovery abuses when considering how to sanction violators. Hence, the Court should not have revived the presumption of fact theory and instead should have

92. The jurisdiction establishment sanction may still be necessary in this situation, since presence of assets alone is not a sufficient basis for personal jurisdiction. Shaffer v. Heitner, 433 U.S. 186, 213 (1977).

93. Insurance Corp. of Ircland, $102 \mathrm{~S}$. Ct. at 2108; cf. Comment, supra note 88, at 704-06 (meeting a similar argument in the context of defending a minimun contacts standard for personal jurisdiction over aliens). Because of due process guarantees, foreign courts are more likely to criticize the substance of American law than the procedures of American courts. See, e.g., Commonwealth Nations Adopt Resolution Criticizing U.S. Treble Damage Judgments, [Apr.-June] Antitrust \& Trade Reg. Rep. (BNA) No. 963, at A-10 (May 8, 1980). In fact, the establishment sanction with its due process guarantee is more protective of defendants' procedural rights than are many foreign systems. See, e.g., Judgment of June 29, 1949, Cour d'appel, Paris, 1949 Recueil Dalloz, Jurisprudence [D. Jur.] 353 (French nationality of plaintiff is sufficient for French court to exercise jurisdiction over foreign corporate defendant); see also G. BACH, EcoNomics: AN INTRoduction to ANALYSis AND Policy 287 (8th ed. 1974) (the efficiency of commerce is improved by greater access to courts within the due process framework). See generally M. KATZ \& K. Brewster, The LaW of International Transactions and Relations 203 (1960).

94. See Hilton v. Guyot, 159 U.S. 113, 163-64 (1895); Comment, supra note 88, at 705-06; Comment, The Minimum Contacts Standard and Alien Defendants, 12 L. \& PoL'Y INT'L Bus. 783, 819 (1980). 
recognized the jurisdiction establishment sanction as the natural result of the courts' sole authority to determine their own jurisdiction.

Robert J. Faris*

* B.A. 1980, Reed College; third-year student, Boalt Hall School of Law, University of California, Berkeley. 